University of Nebraska - Lincoln

DigitalCommons@University of Nebraska - Lincoln

Agronomy \& Horticulture -- Faculty Publications

Agronomy and Horticulture Department

4-1939

\title{
Effects of Frequent Clipping on the Underground Food Reserves of Certain Prairie Grasses
}

\author{
F. S. Bukey \\ University of Nebraska-Lincoln \\ J. E. Weaver \\ University of Nebraska-Lincoln
}

Follow this and additional works at: https://digitalcommons.unl.edu/agronomyfacpub

Part of the Plant Sciences Commons

Bukey, F. S. and Weaver, J. E., "Effects of Frequent Clipping on the Underground Food Reserves of Certain Prairie Grasses" (1939). Agronomy \& Horticulture -- Faculty Publications. 454.

https://digitalcommons.unl.edu/agronomyfacpub/454

This Article is brought to you for free and open access by the Agronomy and Horticulture Department at DigitalCommons@University of Nebraska - Lincoln. It has been accepted for inclusion in Agronomy \& Horticulture -Faculty Publications by an authorized administrator of DigitalCommons@University of Nebraska - Lincoln. 


\title{
EFFECTS OF FREQUENT CLIPPING ON THE UNDERGROUND FOOD RESERVES OF CERTAIN PRAIRIE GRASSES ${ }^{1}$
}

\author{
F. S. Bukey and J. E. Weaver \\ University of Nebraska, Lincoln, Nebraska
}

A series of experiments in which true-prairie grasses were clipped at frequent intervals afforded excellent materials for a study of the effects of such treatment upon the food reserves. Two species of Andropogon, at present the most important dominants of true prairie, were employed. A series of quadrats on a north-facing slope in the Belmont prairie at Lincoln, Nebraska, in which little bluestem, Andropogon scoparius, grew in about 70 per cent pure stand, was the source of one lot of underground parts. Those of big bluestem, A. furcatus, were obtained about a mile distant from virgin lowland prairie near the flood plain of Salt Creek.

Permanent quadrats were marked out in the spring of 1933. The grasses in some were used for controls; in others they were cut close to the ground (in this manner simulating very closely grazed pastures) six times during the growing season, viz. May 9 and 27, June 25, July 27, August 27, and October 10. During the drought year of 1934 the grasses were clipped only four times, May 15, June 13, July 22, and September 27. Only two clippings were made during 1935, due to a dry spring and extreme drought after midsummer. Control quadrats were clipped once each year in October. The last samples were collected on July 25, 1935, after vegetative growth was completed.

Samples consisted of the bases of the culms of the little bluestem occurring below ground and the roots to a depth of 10 centimeters. Big bluestem has, in addition, pronounced shallow rhizomes, which were also taken to the 10centimeter depth. At each sampling materials were secured from both clipped and control quadrats. These were freed from all soil and other foreign matter and then rapidly air dried. After the first year, especially, the samples from the clipped quadrats represented not the average of the whole quadrat but rather the average of the remaining living plants. For example, one-fourth square meter of a control quadrat furnished an abundance of materials from which the samples for chemical analyses could be taken. A sample from the clipped quadrats required much more area-finally over a square meter to secure adequate materials. Although many plants had died, roots and rhizomes were not taken from these, at least not in quantity, since they were often too fragile to withstand the severe brushing necessary thor-

${ }^{1}$ Contribution no. 111 from the Department of Botany, University of Nebraska. 
oughly to cleanse them from soil. Moreover, the species could not always be identified with certainty from these dead remains.

The grasses were in a vigorous condition before the experiment was begun, since both tracts were virgin, unpastured prairie, and rainfall had been adequate for an excellent growth. They had been mowed annually in the fall for the crop of hay.

The initial sampling was done on April 4, 1934, after one year of close clipping, and before growth had been renewed. The second lot of samples was dug on June 16, three days after the second seasonal clipping. Grasses in the control upland plots were 9 inches tall and those in the lowland 12 inches. A third sampling was made in the clipped plots in October, after the plants had completed growth. In 1935, samples were secured from both clipped plots and controls, after the grasses in the latter had completed growth late in July.

The purpose of the chemical study was to make such determinations as would give direct information on the amount of stored food materials. It was believed that the loss in organic materials would increase the percentage of ash, due to a decrease in weight of the organic food materials while the inorganic portion remained constant. Hence, determinations of the total ash and insoluble ash were made. Determinations were also made of the invert sugar, the water-soluble hydrolyzable materials, water-insoluble hydrolyzable materials, pentosans, and nitrogen. They all have a direct bearing on the stored materials which are essential to continued growth of the plants.

Samples for analysis were obtained by grinding the air-dried underground stems and roots in a Wiley mill, using a $.5 \mathrm{~mm}$. screen. The finely ground material was then placed in a pebble mill and reduced to a very fine powder. It was thought that the latter treatment might increase the silica content of the ash. However, results obtained from material directly from the Wiley mill were compared with those obtained from the pebble mill. They showed that the loss of silica from the pebble mill was negligible. Materials were pulverized in order to insure complete extraction for the carbohydrate determinations. Three samples were used in each assay in order to assure comparable results. In nearly all cases there was close agreement among the triplicate samples. Averages of the determination were employed.

\section{Methods of Analysis}

The methods of analysis used in these procedures will be stated only briefly since the exact methods may be found in the "Methods of Analysis," published by the Association of Official Agricultural Chemists.

The determination of ash was made by burning at a low temperature ( $550^{\circ}$ C., dull redness) a desired sample of the dry powdered material until a white ash of constant weight was obtained.

The acid insoluble ash was determined from the ash samples by heating with hydrochloric acid (dilution 1 to 2.5 ) for 5 minutes, then transferring 
to a tared Gooch crucible, washing with water, and then igniting to a constant weight.

The determination of the invert sugar was made by using $10 \mathrm{gm}$. of the air-dried material. This was placed in a $250 \mathrm{cc}$. volumetric flask, $150 \mathrm{cc}$. of alcohol ( 50 per cent by volume) were added and the mixture heated on a water bath for one hour. The flask was removed from the water bath after heating and allowed to stand over night. It was next made up to the $250 \mathrm{cc}$. mark with 95 per cent alcohol, filtered, and $200 \mathrm{cc}$. of the filtrate evaporated to about $20 \mathrm{cc}$. This was placed in a $100 \mathrm{cc}$. volumetric flask and cleared with lead acetate and sodium carbonate. A sample of $25 \mathrm{cc}$. of this filtrate was used for a determination by the Munson and Walker method for invert sugar.

The water-soluble hydrolyzable material was determined by using a $50 \mathrm{cc}$. sample of the above filtrate. This was neutralized with acetic acid after which $5 \mathrm{cc}$. of hydrochloric acid were added and the mixture allowed to stand 24 hours for hydrolysis. The solution was then neutralized with sodium carbonate, $50 \mathrm{cc}$. of this solution were used for a Munson and Walker determination of the total invert sugar.

The water-insoluble hydrolyzable material was determined by using 2.5 $\mathrm{gm}$. of the material which was mixed with $50 \mathrm{cc}$. of water and allowed to stand for 1 hour. This was then placed in a filter and washed with $250 \mathrm{cc}$. of cold water to remove the soluble portion. The insoluble residue was transferred to a $250 \mathrm{cc}$. volumetric flask to which $200 \mathrm{cc}$. of water and $20 \mathrm{cc}$. of hydrochloric acid (dilution 5 to 4 ) were added and the mixture refluxed for 2.5 hours. After neutralizing and clearing, a determination of the reducing value after hydrolysis was made by using the Munson and Walker method. The results were reported as invert sugar.

The determination of nitrogen was made by using the Kjeldahl method with Gunning's modification.

The pentosans were determined by distilling a desired quantity of the ground material with dilute hydrochloric acid. The distillate, which measured $350 \mathrm{cc}$., was precipitated with phloroglucin. This precipitate was collected in a tared Gooch crucible, thoroughly washed, dried to constant weight, and from this value, using the designated factor, the weight of apparent pentosans was calculated.

\section{Results}

The total ash and acid insoluble ash of the roots and underground stems are given in table I.

An inspection of the table shows that the proportional increase in percentage of ash due to the loss in organic material, which was expected, did not occur. In fact, there does not seem to be any constant trend in increasing or decreasing quantities of ash. This may be due to the tiny particles of soil which adhered so tightly to the roots and rhizomes that it was im- 
possible to remove them. It should be pointed out, however, that the samples used were free from all visible soil particles. The individual analyses in most cases varied not more than .05 per cent which indicated that the material was of uniform composition.

TABLE I. Percentage of total ash and acid insoluble ash of roots and underground stems of Andropogon furcatus $(A f)$ and $A$. scoparius $(A s)$ in the surface four inches of soil

\begin{tabular}{|c|c|c|c|c|c|c|c|c|}
\hline \multirow{2}{*}{$\begin{array}{c}\text { Time } \\
\text { of } \\
\text { sampling }\end{array}$} & \multicolumn{2}{|c|}{ Roots of Af } & \multicolumn{2}{|c|}{ Rhizomes of Af } & \multicolumn{2}{|c|}{ Roots of As } & \multicolumn{2}{|c|}{ Stem bases of $A s$} \\
\hline & $\begin{array}{c}\text { Con- } \\
\text { trol }\end{array}$ & Clipped & $\begin{array}{l}\text { Con- } \\
\text { trol }\end{array}$ & Clipped & $\begin{array}{l}\text { Con- } \\
\text { trol }\end{array}$ & Clipped & $\begin{array}{c}\text { Con- } \\
\text { trol }\end{array}$ & Clipped \\
\hline \multicolumn{9}{|c|}{ A. Total ash } \\
\hline $\begin{array}{l}\text { April } 4,1934 \\
\text { June } 16,1934 \\
\text { Oct. } 15,1934 \\
\text { July } 25,1935\end{array}$ & $\begin{array}{l}7.23 \\
6.14 \\
\overline{6.80}\end{array}$ & $\begin{array}{l}8.97 \\
7.63 \\
8.86 \\
7.48\end{array}$ & $\begin{array}{l}8.25 \\
5.91 \\
\overline{5.92}\end{array}$ & $\begin{array}{l}6.51 \\
8.92 \\
6.36 \\
6.46\end{array}$ & $\begin{array}{l}8.34 \\
5.87 \\
6.48\end{array}$ & $\begin{array}{l}7.25 \\
6.69 \\
5.71 \\
6.36\end{array}$ & $\begin{array}{l}5.98 \\
8.12 \\
\overline{4.39}\end{array}$ & $\begin{array}{l}8.64 \\
6.87 \\
4.45 \\
6.80\end{array}$ \\
\hline \multicolumn{9}{|c|}{$B$. Acid insoluble ash } \\
\hline $\begin{array}{l}\text { April } 4,1934 \\
\text { June } 16,1934 \\
\text { Oct. } 15,1934 \\
\text { July } 25,1935\end{array}$ & $\begin{array}{l}6.18 \\
5.19 \\
\overline{6.43}\end{array}$ & $\begin{array}{l}7.59 \\
7.43 \\
7.08 \\
6.27\end{array}$ & $\begin{array}{l}6.65 \\
5.03 \\
\overline{4.90}\end{array}$ & $\begin{array}{l}5.57 \\
6.50 \\
4.38 \\
4.79\end{array}$ & $\begin{array}{l}7.19 \\
4.63 \\
5.56\end{array}$ & $\begin{array}{l}6.59 \\
6.14 \\
4.98 \\
5.46\end{array}$ & $\begin{array}{l}4.75 \\
7.32 \\
-\overline{3.87}\end{array}$ & $\begin{array}{l}7.55 \\
6.13 \\
3.58 \\
5.06\end{array}$ \\
\hline
\end{tabular}

The invert sugar, the water-soluble materials, and the water-insoluble materials capable of reduction of the cupric ion after hydrolysis are shown in table II. From these data, one is able to obtain some iclea of the relative proportion of the food distribution in these grasses.

The small amount of invert sugar represented by the samples collected in April may be accounted for by the fact that although the grasses had not broken dormancy, a few swollen buds were observed while washing the rhizomes. It is also obvious that the percentage was less for the clipped than the control samples, with the exception of the stem bases of little bluestem. These results were obtained from the material after one year of clipping. The second lot of samples, from the control and clipped areas on June 16, 1934, showed in every case a lower percentage of invert sugar in the clipped than in the control samples, although the total percentages were much higher than earlier in the season. In October, after the plants had completed their growth, the results were more nearly comparable to the values obtained in April of the same year. The difference between the results of June and October are to be expected, since there are more soluble nutrients in a growing plant than in one that is dormant.

In 1935, the samples were collected after the plants had completed their 
TABLE II. Percentages of invert sugar, the water-soluble hydrolyzable material and waterinsoluble hydrolyzable material expressed as invert sugar for the roots and underground stems of $A$ ndropogon furcatus $(A f)$ and $A$. scoparius $(A s)$ in the surface four inches of the soil

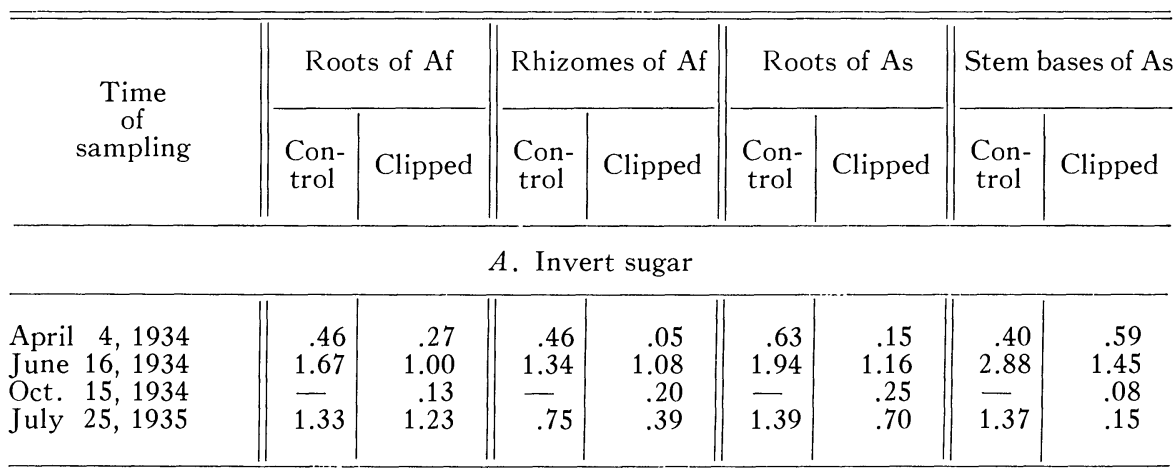

$B$. Water-soluble hydrolyzable material as invert sugar

\begin{tabular}{l||l|l||l|l||l|l||r|r}
\hline April 4, 1934 & 3.13 & 1.21 & 4.08 & 3.47 & 3.85 & 3.21 & 5.22 & 2.71 \\
June 16, 1934 & 1.97 & 2.01 & 1.78 & 1.44 & 2.35 & 1.45 & .98 & .63 \\
Oct. 15, 1934 & - & 2.12 & - & 1.80 & - & 1.24 & - & 1.31 \\
July 25, 1935 & 1.27 & 1.06 & 1.12 & .46 & 1.81 & .74 & 1.48 & .66 \\
\hline
\end{tabular}

C. Water-insoluble hydrolyzable material as invert sugar

April 4,1934

June 16, 1934

Oct. 15, 1934

July 25, 1935

\begin{tabular}{|c|c|c|c|c|c|c|c|}
\hline 27.39 & 14.79 & 31.93 & 25.15 & 28.11 & 25.84 & 27.99 & 27.73 \\
\hline 26.50 & 25.95 & 27.23 & 27.48 & 27.98 & 27.70 & 29.24 & 30.94 \\
\hline 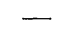 & 17.53 & - & 18.70 & - & 16.12 & - & 13.78 \\
\hline 21.45 & 20.72 & 14.68 & 18.49 & 24.21 & 9.36 & 21.08 & 13.97 \\
\hline
\end{tabular}

vegetative growth. The controls gave much lower values than in June, 1934. This probably resulted from the very dry spring. Comparison of the controls with the clipped samples of July, 1935, shows a very decided decrease in the percentage of invert sugar. A comparison of both the control and the clipped samples for 1934 and 1935 shows the effect of severe clipping over a period of three years upon the food reserves in the form of soluble invert sugars. In big blustem the amount in the roots of both control and clipped plants usually greatly exceeded that of the rhizomes. In little bluestem, where the stem bases are much more limited storage organs, this relationship did not hold. The low percentage for the clipped samples in 1935 corresponded with the lowered vitality of the plants, and the death of many of them.

A study of parts B and C of table II shows that the clipped grasses without exception, had less water-soluble hydrolyzable material and water-insoluble hydrolyzable material on April 4, 1934, than their controls. A decrease in percentage of food materials for both the clipped and control grasses was noted, however, as in A, from 1934 to 1935.

Table III is divided into two parts, A, the percentage of pentosans as 
calculated from the furfural produced in the experiments, and $\mathrm{B}$, the percentage of nitrogen.

TABLE III. Pentosans and nitrogen of roots and underground stems of Andropogon furcatus $\left(A f^{*}\right)$ and $A$. scoparius $(A s)$ in the surface four inches of soil

\begin{tabular}{|c|c|c|c|c|c|c|c|c|}
\hline \multirow{2}{*}{$\begin{array}{c}\text { Time } \\
\text { of } \\
\text { sampling }\end{array}$} & \multicolumn{2}{|c|}{ Roots of Af } & \multicolumn{2}{|c|}{ Rhizomes of Af } & \multicolumn{2}{|c|}{ Roots of As } & \multicolumn{2}{|c|}{ Stem bases of As } \\
\hline & $\begin{array}{c}\text { Con- } \\
\text { trol }\end{array}$ & Clipped & $\begin{array}{l}\text { Con- } \\
\text { trol }\end{array}$ & Clipped & $\begin{array}{l}\text { Con- } \\
\text { trol }\end{array}$ & Clipped & $\begin{array}{l}\text { Con- } \\
\text { trol }\end{array}$ & Clipped \\
\hline \multicolumn{9}{|c|}{ A. Pentosans } \\
\hline $\begin{array}{lr}\text { April } & 4,1934 \\
\text { June } 16,1934 \\
\text { Oct. } 15,1934 \\
\text { July } 25,1935\end{array}$ & $\begin{array}{l}17.08 \\
21.92 \\
20.68\end{array}$ & $\begin{array}{l}21.30 \\
23.52 \\
19.83 \\
10.08\end{array}$ & $\begin{array}{l}24.38 \\
24.72 \\
22.52\end{array}$ & $\begin{array}{l}15.68 \\
23.93 \\
22.46 \\
24.19\end{array}$ & $\begin{array}{c}18.36 \\
24.68 \\
- \\
9.09\end{array}$ & $\begin{array}{l}14.78 \\
24.36 \\
21.13 \\
22.71\end{array}$ & $\begin{array}{c}22.71 \\
30.19 \\
-\overline{23.71}\end{array}$ & $\begin{array}{l}25.74 \\
26.86 \\
26.80 \\
24.71\end{array}$ \\
\hline \multicolumn{9}{|c|}{$B$. Nitrogen } \\
\hline $\begin{array}{l}\text { April } 4,1934 \\
\text { June } 16,1934 \\
\text { Oct. } 15,1934 \\
\text { July } 25,1935\end{array}$ & $\begin{array}{l}.68 \\
.58 \\
.60\end{array}$ & $\begin{array}{l}.75 \\
.51 \\
.59 \\
.46\end{array}$ & $\begin{array}{l}.76 \\
.46 \\
.73\end{array}$ & $\begin{array}{l}.72 \\
.61 \\
.73 \\
.75\end{array}$ & $\begin{array}{l}.77 \\
.42 \\
-72\end{array}$ & $\begin{array}{l}.66 \\
.47 \\
.60 \\
.78\end{array}$ & $\begin{array}{l}.76 \\
.48 \\
-74\end{array}$ & $\begin{array}{l}.69 \\
.51 \\
.61 \\
.75\end{array}$ \\
\hline
\end{tabular}

This portion of the study gave a series of very erratic results from which it would be difficult to draw any conclusions. It may be noticed that there was less change in the percentage of pentosan in the rhizomes and stem bases than in the roots, although the values remained relatively constant over the twoyear period. This may be due to the abundance of bract-like appendages over the surface of these stems which under the conditions of the experiment would no doubt yield quantities of furfural. The roots, being of different structure, would yield a smaller amount of furfural and would, therefore, have a lower percentage.

As nearly constant results were obtained in determinations of nitrogen as might be expected from plant material of this type. The results show almost a constant nitrogen balance even under adverse conditions of growth. It may be noticed that the lowest percentages were found in the samples of June 16, of the extremely dry year 1934 .

\section{Conclusions}

The percentage of ash and acid insoluble ash gave no insight into the quantity of food reserves of the plant.

The ash content varied between 4.4 and 9 per cent and the acid insoluble ash between 3.6 and 7.6 per cent.

There was a marked decrease in the percentage of invert sugar, water- 
soluble hydrolyzable material and water-insoluble hydrolyzable material under conditions of severe clipping.

Drought during 1934 and 1935 had a similar but smaller effect on the stored nutrients of the control plants for comparable periods (June and July).

The pentosan determination, owing to the formation of furfural from stem parts, proved of little value in the determination of nutrients.

The percentage of nitrogen was almost constant, varying approximately between .42 and .78 per cent under all the conditions of growth studied.

Severe clipping of Andropogon scoparius and A. furcatus decreases the amount of foods stored by the plants in their roots, thus resulting in their destruction in a period of a few years. 